\title{
ОБЗОРЫ
}

\section{Агентские конфликты и концентрация собственности}

\author{
Анисинкова Д.С. ${ }^{25}$, Балясникова МА. ${ }^{26}$, Волотовская О.А. ${ }^{27}$
}

Целью данного обзора является классификация исследований по проблемам агентских конфликтов миноритарных и мажсоритарных акционеров и концентрачии собственности. Данные проблемы тесно связаны между собой, а также с агентскими конфликтами «менеджер - собственник». Концентращия капитала представляет собой распределение прав собственности между акционерами. Исследования конщентрации собственности рассматривают следующие вопросы: сколько в компании крупных и миноритарных акционеров; сколько менеджеров-акционеров; являются ли менеджеры крупными или миноритарными акционерами; как концентрация воздействует на показатели результативности компании; какие факторы влияют на концентрацию собственного капитала; каковы издержки агентских конфликтов миноритариев и мажоритариев и др. Близость проблемь концентрации собственности и агентской проблемы «менеджер собственник» обусловлена тем, что в ряде случаев менеджеры выступают в роли крупных акционеров наряду с другими собственниками. В этих ситуациях гипотезы стимулов, окапьввания и издержки мониторинга и контроля, а также их влияние на результатьл деятельности фирмы следует рассматривать совместно.

JEL: $G 32$

Ключевые слова: концентрачия собственности, миноритарные акционеры, мажсоритарные акциионеры, издержки концентрации собственности, агентские издержки.

\section{Причины появления концентрации собственности}

Авторы в своих работах выделяют разные причины появления концентрации. Сравнительный анализ этих факторов приведен в таблице 1. Фама и Йенсен [Fama, Jensen, 1983] рассматривают организацию как совокупность контрактов. Авторы выдвигают две гипотезы:

1. Если объединение функций управления и контроля эффективно в рамках нескольких агентов - то так же эффективно, чтобы эти агенты несли остаточный риск.

2. Отделение функции управления от агентов, несущих остаточный риск, делает необходимым разделение функций управления и контроля.

Рассматриваются две ситуации. Первая - с неполнотой информации: для организации выгодно сосредоточить на информированных агентах функции управления и контроля, но так как велика вероятность оппортунистического поведения с их стороны, на них также перекладывается остаточный риск, что ведет к концентрации. Вторая - с полной информацией: при этом из-за выгод от специализации менеджеров происходит отделение функции управления от агентов, несущих остаточный риск, а вопрос эффективного контроля решается двумя способами: делегирование полномочий совету директоров или концентрация собственности.

\footnotetext{
${ }^{25}$ Магистр программы «Стратегическое управление финансами фирмы» ГУ ВШЭ

${ }^{26}$ Магистр программы «Стратегическое управление финансами фирмы» ГУ ВШЭ.

27 Стажер-исследователь научно-учебной лаборатории корпоративных финансов, магистр программы «Стратегическое управление финансами фирмы» ГУ ВШЭ.

Выпуск \#2(14), 2010

() Электронный журнал Корпоративные Финансы, 2010
} 
При рассмотрении факторов, влияющих на появление концентрации собственности, Демсец и Лен [Demsetz, Lehn, 1985] выделяют большой размер компании, неопределенность внешней среды и наличие встроенных ограничений. Авторы приводят следующие взаимосвязи. Если фирма большая, ее потребность в капитале выше. Если она привлекает этот капитал от небольшого количества крупных акционеров, то у акционеров снижается диверсификация портфелей и растет риск. Такие акционеры потребуют большую доходность, чтобы компенсировать риск, поэтому стоимость капитала тем больше, чем больше фирме его нужно. Крупные фирмы будут стремиться привлекать капитал дешевле, что приведет к большому количеству мелких акционеров, а это снижает концентрацию собственности. При высокой неопределенности внешней среды, у фирмы нестабильные доходы, издержки, прочие показатели, поэтому собственнику сложнее контролировать результаты деятельности менеджеров, так как среда деятельности фирмы создает дополнительные «шумы». Для достижения поставленных целей контроль со стороны собственников должен быть более жестким, что возможно при небольшом количестве крупных собственников, поэтому концентрация собственности растет. Встроенные ограничения, такие как существование регламента по поводу действий менеджеров, снижают риск оппортунизма, что облегчает задачу контроля для собственников. Тогда издержки мониторинга ниже, и у собственников нет стимула укрупняться, поэтому концентрация собственности снижается.

В своем исследовании Ненова [Nenova, 2002] выделяет фактор развитости юридической среды (степень защиты инвестора, регулирование сделок слияний/поглощений, ограничения на права акционеров), а Дик и Зингалес [Dyck, Zingales, $2004]$ - фактор развитости институциональной среды (правовое регулирование, степень конкурентности отрасли, общественное мнение, степень развитости СМИ, моральные нормы, развитость налогового регулирования, развитость финансового рынка), как основной источник появления концентрации собственности. В случае неразвитости данных институтов выгода от оппортунистического поведения увеличивается, а степень концентрации возрастает.

Развитость финансового рынка подразумевает под собой также и большую ликвидность и прозрачность. Степень концентрации собственности будет расти, так как инвесторам проще реализовать свой крупный пакет, они не будут запрашивать за это большую стоимость капитала, и фирмы будут готовы распределять акции между крупными акционерами.

Таблица 1

Причины появления концентрации собственности

\begin{tabular}{|c|c|c|c|c|}
\hline Исследование & Фактор влияния & Издержки & Выгоды & Результат \\
\hline \multirow{2}{*}{$\begin{array}{l}\text { Фама, Йенсен } \\
\text { [Fama, Jensen } \\
\text { 1983] }\end{array}$} & Неполнота информации & $\begin{array}{l}\text { 1) Издержки асимметрии } \\
\text { информации } \\
\text { 2) Издержки контроля } \\
\text { 3) Наличие остаточного } \\
\text { риска }\end{array}$ & $\begin{array}{l}\text { Обладание уникальной } \\
\text { информацией }\end{array}$ & $\begin{array}{l}\text { Рост } \\
\text { концентрации }\end{array}$ \\
\hline & Полная информация & Издержки контроля & $\begin{array}{l}\text { 1) Полная информация } \\
\text { 2) Специализация } \\
\text { 3) Незапрещенное } \\
\text { разделение рисков }\end{array}$ & $\begin{array}{l}\text { 1) Рост } \\
\text { концентрации } \\
\text { 2) Делегирование } \\
+ \\
\text { разделение } \\
\text { функций } \\
\end{array}$ \\
\hline \multirow{2}{*}{$\begin{array}{l}\text { Демсец, Лен } \\
{[\text { Demsetz, Lehn }} \\
1985]\end{array}$} & Большой размер фирмы & $\begin{array}{l}\text { Более высокие расходы на } \\
\text { капитал }\end{array}$ & $\begin{array}{l}\text { Низкие агентские } \\
\text { издержки }\end{array}$ & $\begin{array}{l}\text { Снижение } \\
\text { концентрации }\end{array}$ \\
\hline & $\begin{array}{l}\text { Риск/неопределенность } \\
\text { во внешней среде }\end{array}$ & $\begin{array}{l}\text { Возрастают издержки } \\
\text { мониторинга менеджеров }\end{array}$ & $\begin{array}{l}\text { Высокая отдача от } \\
\text { жесткого контроля }\end{array}$ & $\begin{array}{l}\text { Рост } \\
\text { концентрации }\end{array}$ \\
\hline
\end{tabular}




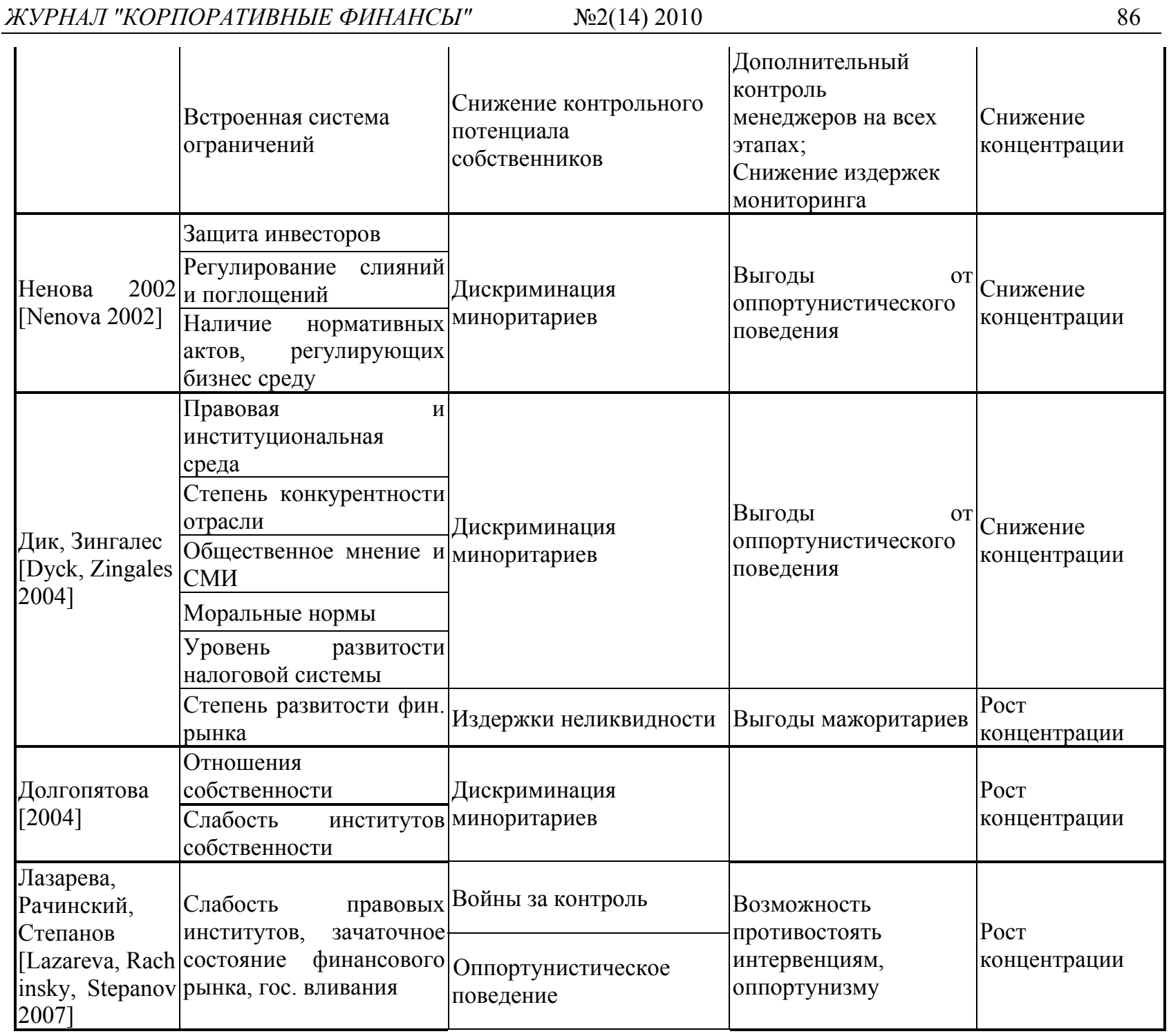

Исследование интеграционных процессов, протекающих в российской экономике после 1998 года, на основе интервью с руководителями 20 открытых акционерных обществ провела Долгопятова [2004]. Интеграционные процессы и, как следствие, высокий уровень концентрации - характерная черта современной российской экономики. Автор выделила ряд основных причин высокой степени концентрации собственности. Во-первых, интеграция способствует повышению конкурентоспособности и увеличению доли компании на рынке за счет экономии на издержках. Во-вторых, концентрация рассматривалась собственниками как страховка хозяйственных связей и вложенного капитала, а также как средство защиты от враждебного поглощения в условиях слабых правовых институтов.

Лазарева, Рачинский и Степанов [Lazareva, Rachinsky, Stepanov, 2007] среди причин роста концентрации собственности в России выделяют институциональные факторы: слабость юридической системы, риск экспроприации, неразвитость фондового рынка, коррупция.

\section{Концентрация собственности и эффективность компании}

Исследования взаимосвязи концентрации и эффективности можно разделить на две группы. Первая рассматривает концентрацию как эндогенную. Концентрация собственности определяется целями фирмы по максимизации благосостояния ее акционеров, а обратной зависимости нет. Другая группа, напротив, обнаруживает влияние концентрации собственности (в руках менеджеров или внешних крупных акционеров) на показатели 
эффективности фирмы. В большинстве исследований рассматриваются стоимость компании и Q Тобина, в отдельных и ранних - прибыль. Ниже приведена сводная таблица 2 по рассмотренным работам.

Демсец [Demsetz, 1983] рассматривает три вида показателей концентрации и подтверждает, что она эндогенна и зависит от интересов акционеров и состояния рынка акций. Демсец и Лен [Demsetz, Lehn, 1985] используют дополнительный показатель коэффициент Герфиндаля - и делают вывод о том, что концентрация собственности не влияет на рентабельность.

Названные исследования используют рентабельность как показатель эффективности фирмы. Он характеризуется назадсмотрящей динамикой, в то время как Q Тобина впередсмотрящей, что, возможно, могло бы объяснять отсутствие влияния концентрации на результативность. Однако проведенное Демсецем и Вилланога [Demsetz, Villanoga, 2001] исследование показывает, что Q Тобина не зависит от концентрации, а также от доли акций у топ-менеджеров. Их выводы согласуются с гипотезой о том, что структура собственности эндогенна и выбирается таким образом, чтобы максимизировать стоимость фирмы.

Противоположная точка зрения обусловлена тем, что до определенной степени доля в собственности выступает для менеджеров как стимул, и уменьшает агентские издержки, стоимость фирмы растет. Однако с определенного момента менеджеры могут пренебрегать контролем со стороны внешних инвесторов и использовать фирму для достижения собственных, не максимизирующих стоимость целей. Так, Морк, Шлейфер и Вишни [Morck, Shleifer, Vishny, 1988] при помощи кусочной регрессии устанавливают наличие значимой нелинейной зависимости: рост $\mathrm{Q}$ Тобина на участке от 0 до 5\%, падение после 5\% собственности менеджеров. Макконнел и Серваэс [McConnell, Servaes, 1990] подтверждают нелинейную зависимость, которая, начиная с доли, равной 40-50\%, становится отрицательной. Дэвис, Хиллер и Макколган [Davies, Hillier, McColgan, 2005] помимо нелинейной зависимости выделяют наличие второго возрастающего участка Q Тобина на интервале 75-100\%, где менеджеры, являясь единоличными собственниками, придерживаются максимизации стоимости фирмы в целом.

Ивашковская и Степанова [2009] продолжили исследование влияния концентрации собственности на стратегическую эффективность компании на основе интегрированного взгляда в рамках анализа финансовой архитектуры. Они провели межстрановой анализ эффективности, используя коэффициент Q Тобина. Построенная выборка состояла из 166 компаний из девяти европейских стран по 11 секторам экономики. В качестве независимых переменных использовались показатели концентрации собственности в руках менеджеров и членов совета директоров; институциональных инвесторов; доля акционеров, владеющих крупным пакетом акций и занятых активным управлением.

По результатам исследования Ивашковская и Степанова пришли к следующим выводам.

- Доля акционерного капитала в руках менеджеров не имеет значимого влияния на корпоративную эффективность. Гипотеза об U-образной форме зависимости отвергается.

- Увеличение собственности акционеров, вовлеченных в управление компанией, ведет к росту эффективности.

- Собственность институциональных инвесторов не оказывает значимого влияния на эффективность.

- Рост количества акций в руках государства и аффилированных лиц оказывает, как правило, отрицательное влияние, однако характер влияния зависит от силы власти. Отрицательное влияние может объясняться рестриктивной функцией государства.

- Концентрация собственности в модели имеет экзогенный характер.

Ивашковская и Зинкевич [2009] исследуют панельную выборку 270 немецких компаний с 2000 по 2006 год. Германия интересна из-за сходства системы ее корпоративного управления с развивающимися странами (высокая концентрация, инсайдеры 
- доминирующие собственники) и реализации так называемого «натурального эксперимента» [cм. Black, Jang, Kim, 2006]: в 2002 году был отменен 50\%-ный налог на доходы с продажи акций, которые были в собственности более года. Для высококонцентрированных систем с высокими издержками на изменение этой структуры наблюдается перераспределение собственности после отмены налога. Авторы выявили отрицательное влияние доли инсайдеров и положительное - доли институциональных инвесторов на эффективность. Разработанная методология ценна тем, что может быть использована для данных с развивающихся рынков, в том числе для России.

\section{Концентрация собственности и эффективность компании: российский опыт}

В своей статье Капелюшников [2000] объединяет итоги трех исследований, проведенных Русским Экономическим Барометром в 1995, 1997 и 1999 годах. В качестве показателя концентрации автор выбрал долю крупнейшего акционера, которая в среднем по данным равна 30\%. В качестве индикаторов эффективности - наполненность портфеля заказов, загрузка производственных мощностей и рабочей силы. Результаты говорят о нелинейной зависимости: самые эффективные фирмы имеют невысокую концентрацию собственности (10-20\%), у неэффективных, наоборот, высока доля главного собственника государства или нефинансовой структуры. Если в качестве мажоритариев выступали менеджеры или внешние финансовые структуры, то фирмы оказывались эффективнее.

Статья Кузнецова и Муравьева [Kuznetsov, Muravyev, 2000] исследует влияние концентрации собственности на эффективность «голубых фишек» российского фондового рынка. Авторы используют два показателя концентрации: долю голосующих акций в руках трех крупнейших акционеров и долю трех крупнейших негосударственных акционеров, чтобы выявить влияние государственного участия. Индикаторами эффективности выбраны Q Тобина, рентабельность и производительность труда. Авторы пришли к выводу, что структура собственности слабо влияет на производительность труда, а полученная Uобразная связь между структурой собственности и рентабельностью интерпретируется как наличие конфликта между миноритариями и крупными собственниками по поводу распределения прибыли. Вторым результатом является отрицательная зависимость Q Тобина от концентрации: выгоды от увеличения концентрации собственности перекрываются негативным эффектом экспроприации мелких акционеров крупными собственниками. В таблице 3 приведены сводные результаты исследований для российского рынка.

Долгопятова [2004] (см. выше) на основе выборки из 20 российских компаний установила, что высокий уровень концентрации ведет к росту инвестиций и, как следствие, большему использованию кредитных ресурсов. Однако в бизнесе со средним уровнем концентрации текущие показатели динамики выпуска и реструктуризации персонала выше. Низкая концентрация собственности в российских условиях негативно сказывается на результативности в разрезе текущей деятельности компании, инвестиционной политики и стратегического планирования. Компании, основными владельцами которых являются трудовые коллективы, характеризуются самой слабой результативностью.

В работе Энтова и др. [2006] строится модель, объясняющая, почему одни компании более прозрачны, чем другие. Чем выше концентрация собственности в руках крупнейшего акционера, тем выше потенциальная прозрачность. Показано, что эффективным (с точки зрения инвестиций) компаниям выгодно раскрывать информацию для привлечения инвесторов, в то время как для неэффективных это лишь увеличит издержки. Прозрачность рассматривается как положительный сигнал. Регрессионный анализ на российских компаниях подтвердил положительное влияние концентрации на прозрачность, где в качестве показателя прозрачности взята дисперсия прогноза аналитиков относительно цен акций. 
Ивашковская и Степанова [2009] анализировали влияние различных элементов финансовой архитектуры на корпоративную эффективность. Предложенная модель была адаптирована под три подвыборки: западноевропейские компании, российские компании и компании с других развивающихся рынков (суть исследования см. выше). Для России авторы подчеркивают, что эффективность корпоративной деятельности компаний, контролируемых государством, значительно ниже, чем контролируемых одним или несколькими вовлеченными инвесторами. Также авторы пришли к выводу о незначимости влияния долей менеджеров и институциональных инвесторов на корпоративную эффективность исследуемых компаний.

Таблица 2

Сводная таблица по зарубежным исследованиям концентрации собственности и эффективности

\begin{tabular}{|c|c|c|c|c|}
\hline Исследование, год & $\begin{array}{c}\text { Показатель } \\
\text { концентрации }\end{array}$ & $\begin{array}{c}\text { Показатель } \\
\text { эффективност } \\
\text { и } \\
\end{array}$ & $\begin{array}{c}\text { Влияние концентрации на } \\
\text { эффективность }\end{array}$ & \multirow{4}{*}{ 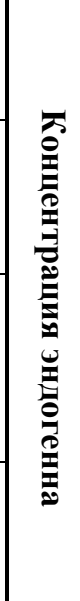 } \\
\hline $\begin{array}{l}\text { Демсец [Demsetz, } \\
\text { 1983] }\end{array}$ & $\begin{array}{l}\text { Доля 5, 10, } 20 \\
\text { крупнейших акционеров }\end{array}$ & Рентабельность & $\begin{array}{l}\text { Концентрация - результат политики } \\
\text { максимизации благосостояния } \\
\text { акционеров, эндогенна }\end{array}$ & \\
\hline $\begin{array}{l}\text { Демсец и Лен } \\
\text { [Demsetz, } \\
\text { Lehn, 1985] }\end{array}$ & $\begin{array}{l}\text { 1) Доля } 5 \text { крупнейших } \\
\text { акционеров } \\
\text { 3) Коэффициент } \\
\text { Герфиндаля }\end{array}$ & Рентабельность & $\begin{array}{l}\text { Концентрация не влияет на } \\
\text { эффективность, эндогенна }\end{array}$ & \\
\hline $\begin{array}{l}\text { Демсец и Вилланога } \\
\text { [Demsetz, Villanoga, } \\
\text { 2001] }\end{array}$ & $\begin{array}{l}\text { 1) Доля } 5 \text { крупнейших } \\
\text { акционеров } \\
\text { 2) Доля топ-менеджеров }\end{array}$ & Q Тобина & $\begin{array}{l}\text { Концентрация не влияет на } \\
\text { эффективность, эндогенна }\end{array}$ & \\
\hline $\begin{array}{l}\text { Морк, Шлейфер и } \\
\text { Вишни [Morck, } \\
\text { Shleifer, Vishny, 1988] }\end{array}$ & Доля топ-менеджеров & Q Тобина & Нелинейное влияние, один максимум & \\
\hline $\begin{array}{l}\text { МакКоннел и Серваэс } \\
{[\text { [McConnell, Servaes, }} \\
\text { 1990] }\end{array}$ & $\begin{array}{l}\text { 1) Доля топ-менеджеров } \\
\text { 2) Доля крупных } \\
\text { акционеров }\end{array}$ & Q Тобина & $\begin{array}{l}\text { Рост индикатора эффективности по } \\
\text { доле собственности менеджеров, } \\
\text { затем снижение } \\
\text { доля крупных акционеров незначима }\end{array}$ & \\
\hline $\begin{array}{l}\text { Дэвис, Хиллер и } \\
\text { МакКолган [Davies, } \\
\text { Hillier, McColgan, } \\
\text { 2005] }\end{array}$ & Доля топ-менеджеров & Q Тобина & $\begin{array}{l}\text { Нелинейное влияние, два локальных } \\
\text { максимума }\end{array}$ & \\
\hline $\begin{array}{l}\text { Ивашковская, } \\
\text { Степанова [2009] }\end{array}$ & $\begin{array}{l}\text { 1) Доля вовлеченных в } \\
\text { управление акционеров } \\
\text { 2) Доля менеджеров } \\
\text { 3) Доля } \\
\text { институциональных } \\
\text { инвесторов } \\
\text { 4) Доля государства и } \\
\text { аффилированных } \\
\text { компаний }\end{array}$ & Q Тобина & $\begin{array}{l}\text { 1) Концентрация собственности в } \\
\text { руках вовлеченных акционеров } \\
\text { положительно влияет на } \\
\text { эффективность } \\
\text { 2) Концентрация собственности в } \\
\text { руках менеджеров и } \\
\text { институциональных инвесторов не } \\
\text { оказывает существенного влияния на } \\
\text { эффективность } \\
\text { 3) Увеличение доли собственности } \\
\text { государства отрицательно } \\
\text { сказывается на корпоративной } \\
\text { эффективности компании }\end{array}$ & \begin{tabular}{|l} 
\\
\end{tabular} \\
\hline $\begin{array}{l}\text { Ивашковская, } \\
\text { Зинкевич [2009] }\end{array}$ & $\begin{array}{l}\text { 1) Доля инсайдеров } \\
\text { 2) Доля финансовых } \\
\text { институтов } \\
\text { 3) Доля } \\
\text { институциональных } \\
\text { инвесторов } \\
\text { 4) Доля государства }\end{array}$ & Q Тобина/ ROA & $\begin{array}{l}\text { 1) Отрицательное влияние } \\
\text { инсайдеров в структуре } \\
\text { собственников на эффективность } \\
\text { 2) Положительный эффект, если } \\
\text { собственниками являются } \\
\text { институциональные инвесторы. }\end{array}$ & \\
\hline
\end{tabular}


Таблица 3

Концентрация собственности и эффективность компании: российский опыт

\begin{tabular}{|c|c|c|c|}
\hline \begin{tabular}{|} 
Исследование, \\
год
\end{tabular} & Концентрация & $\begin{array}{c}\text { Индикатор } \\
\text { эффективности }\end{array}$ & Влияние концентрации на эффективность \\
\hline $\begin{array}{l}\text { Капелюшников } \\
{[2000]}\end{array}$ & $\begin{array}{l}\text { Доля крупнейшего } \\
\text { акционера }\end{array}$ & \begin{tabular}{|l|} 
Наполненность \\
портфеля заказов и \\
др \\
\end{tabular} & $\begin{array}{l}\text { Нелинейная зависимость, компания эффективнее, } \\
\text { когда концентрация низка }\end{array}$ \\
\hline \multirow{2}{*}{$\begin{array}{l}\text { Кузнецов, } \\
\text { Муравьев } \\
{[2000]}\end{array}$} & \multirow{2}{*}{$\begin{array}{l}\text { Доля акций трех } \\
\text { крупнейших } \\
\text { акционеров }\end{array}$} & Q Тобина & $\begin{array}{l}\text { 1) Все собственники: отрицательная, } \\
\text { замедляющаяся зависимость } \\
\text { 2) Частные собственники: отрицательная } \\
\text { зависимость }\end{array}$ \\
\hline & & Рентабельность & $\begin{array}{l}\text { 1) Все собственники: кривая формы U, минимум } \\
\text { при 56\% концентрации } \\
\text { 2) Частные собственники: отрицательная } \\
\text { зависимость, если у государства нет } \\
\text { блокирующего пакета }\end{array}$ \\
\hline \multirow[b]{2}{*}{$\begin{array}{l}\text { Долгопятова } \\
{[2004]}\end{array}$} & $\begin{array}{l}\text { 1) Высокая } \\
\text { 2) Средняя } \\
\text { 3) Низкая }\end{array}$ & \multirow{2}{*}{$\begin{array}{l}\text { Текущие } \\
\text { результаты } \\
\text { компании (выручка, } \\
\text { прибыль и др.) } \\
\text { Инвестиционная } \\
\text { политика компании, } \\
\text { уровень технологий }\end{array}$} & $\begin{array}{l}\text { 1) Высокий уровень концентрации - лучшие } \\
\text { технологии и агрессивная инвестиционная } \\
\text { политика } \\
\text { 2) Средний уровень концентрации - высокие } \\
\text { показатели текущей деятельности } \\
\text { 3) Низкий уровень концентрации - слабые } \\
\text { показатели текущей деятельности } \\
\end{array}$ \\
\hline & $\begin{array}{l}\text { 1) Доля внешних } \\
\text { собственников } \\
\text { 2) Доля менеджеров } \\
\text { 3) Доля иностранных } \\
\text { инвесторов } \\
\text { 4) Доля государства и } \\
\text { аффилированных } \\
\text { компаний } \\
\text { 5) Доля трудовых } \\
\text { коллективов }\end{array}$ & & $\begin{array}{l}\text { 1) Положительная зависимость между долей } \\
\text { внешних собственников и эффективностью } \\
\text { 2) Положительная зависимость между долей } \\
\text { менеджеров и эффективностью } \\
\text { 3) Неоднозначное влияние доли иностранных } \\
\text { инвесторов на эффективность } \\
\text { 4) Не удалось выявить зависимость } \\
\text { 5) Отрицательная зависимость }\end{array}$ \\
\hline $\begin{array}{l}\text { Энтов, } \\
\text { Радыгин, } \\
\text { Межераупс, } \\
\text { Швецов [2006] }\end{array}$ & $\begin{array}{l}\text { 1) Доля крупнейшего } \\
\text { акционера } \\
\text { 2) Суммарная доля } \\
\text { всех крупных } \\
\text { акционеров (более } \\
10 \% \text { акций) } \\
\end{array}$ & $\begin{array}{l}\text { Прозрачность как } \\
\text { сигнал } \\
\text { эффективности }\end{array}$ & $\begin{array}{l}\text { 1) Значимая положительная зависимость } \\
\text { прозрачности от доли крупнейшего акционера } \\
\text { 2) Незначимая зависимость от доли всех крупных } \\
\text { акционеров }\end{array}$ \\
\hline $\begin{array}{l}\text { Ивашковская, } \\
\text { Степанова } \\
{[2009]}\end{array}$ & $\begin{array}{l}\text { 1) Доля вовлеченных } \\
\text { в управление } \\
\text { акционеров } \\
\text { 2) Доля менеджеров } \\
\text { 3) Доля } \\
\text { институциональных } \\
\text { инвесторов } \\
\text { 4) Доля государства и } \\
\text { аффилированных } \\
\text { компаний }\end{array}$ & Q Тобина & $\begin{array}{l}\text { 1) Государственные компании менее } \\
\text { эффективны, чем контролируемые вовлеченными } \\
\text { акционерами. } \\
\text { 2) Концентрация собственности в руках } \\
\text { менеджеров и институциональных инвесторов не } \\
\text { оказывает существенного влияния на } \\
\text { эффективность }\end{array}$ \\
\hline
\end{tabular}

\section{Издержки концентрации собственности}

Исследователи выделяют различные издержки концентрации. Их классификация приведена в таблице 4. 
Таблица 4

Издержки концентрации собственности для стейкхолдеров

\begin{tabular}{|c|c|c|}
\hline Исследование & $\begin{array}{c}\text { Издержки } \\
\text { концентрации } \\
\end{array}$ & Источник издержек \\
\hline Батц [Butz, 1994] & \multirow{6}{*}{$\begin{array}{l}\text { Дискриминация } \\
\text { миноритариев }\end{array}$} & $\begin{array}{l}\text { Оппортунизм } \\
\text { менеджеров }\end{array}$ \\
\hline $\begin{array}{l}\text { Кронквист, Нильссон [Cronqvist, } \\
\text { Nilsson, 2003] }\end{array}$ & & Избыточный контроль \\
\hline Дик, Зингалес [Dyck, Zingales 2004] & & $\begin{array}{l}\text { Использование } \\
\text { инсайдерской } \\
\text { информации }\end{array}$ \\
\hline Долгопятова [2004] & & Нерыночные продажи \\
\hline $\begin{array}{l}\text { Лазарева, Рачинский, Степанов } \\
\text { [Lazareva, Rachinsky, Stepanov 2007] }\end{array}$ & & $\begin{array}{l}\text { Низкие дивиденды; } \\
\text { использование } \\
\text { инсайдерской } \\
\text { информации и } \\
\text { контроля }\end{array}$ \\
\hline Сильвейра, Диас [Silveira, Dias, 2008] & & $\begin{array}{l}\text { Обнародование } \\
\text { конфликтов }\end{array}$ \\
\hline $\begin{array}{l}\text { Буркарт, Громб, Панунзи [Burkart, } \\
\text { Gromb, Panunzi 1997] }\end{array}$ & \multirow{2}{*}{$\begin{array}{l}\text { Снижение } \\
\text { самостоятельности } \\
\text { менеджмента, } \\
\text { упущение прибыльных } \\
\text { возможностей }\end{array}$} & \multirow{2}{*}{$\begin{array}{l}\text { Чрезмерный } \\
\text { мониторинг }\end{array}$} \\
\hline Пагано, Роэль [Pagano, Röell 1998] & & \\
\hline $\begin{array}{l}\text { Болтон, вон Тхаден [Bolton, Von } \\
\text { Thadden 1998] }\end{array}$ & \multirow[t]{2}{*}{ Снижение ликвидности } & \multirow{5}{*}{$\begin{array}{l}\text { Концентрация пакета } \\
\text { акций в одних руках }\end{array}$} \\
\hline Дик, Зингалес [Dyck, Zingales 2004] & & \\
\hline Демсец, Лен [Demsetz, Lehn 1985] & \multirow{3}{*}{$\begin{array}{l}\text { Снижение } \\
\text { возможностей для } \\
\text { диверсификации }\end{array}$} & \\
\hline $\begin{array}{l}\text { Адмати, Пфлайдерер, Зехнер [Admatti, } \\
\text { Pfleiderer, Zechner 1994] }\end{array}$ & & \\
\hline Дик, Зингалес [Dyck, Zingales 2004] & & \\
\hline Дик, Зингалес [Dyck, Zingales 2004] & Потеря репутации & $\begin{array}{l}\text { Оппортунистическое } \\
\text { поведение }\end{array}$ \\
\hline
\end{tabular}

Один из распространенных взглядов - это издержки миноритариев от дискриминации, например, при продаже активов по нерыночной цене или использовании инсайдерской информации о результатах деятельности компании с целью игры на акциях этой же компании [Lazareva, Rachinsky, Stepanov 2007; Dyck, Zingales 2004].

Детально агентскими издержками концентрации занимались следующие авторы: Батц [Butz, 1994], Кронквист, Нильссон [Cronqvist, Nilsson, 2003], Сильвейра и Диас [Silveira, Dias, 2008]

Батц [Butz, 1994] анализирует, каким образом крупные акционеры, не обладающие контрольным пакетом, могут влиять на решения менеджеров. Миноритарный акционер, приобретая долю в собственности, хочет получить отдачу от своих инвестиций. Однако эффективность напрямую зависит от действий менеджеров. Автор считает, что менеджеры и миноритарии вынуждены прибегать к компромиссному решению в возникающем конфликте интересов, не используя затратные меры по установлению контроля (к примеру, за счет скупки дополнительных акций). 
Кронквист и Нильссон [Cronqvist, Nilsson, 2003] построили выборку по 309 шведским фирмам за период 1991-1997 годов и пришли к выводу, что большинство фирм использует систему управления миноритарными акционерами, которая порождает агентские издержки. Кроме того, в Швеции многие фирмы являются семейными, что накладывает на них специфические издержки. Полученные результаты свидетельствуют о том, что фирмы, эксплуатирующие миноритариев, несут потери в стоимости от 6 до 25\%.

Сильвейра и Диас [Silveira, Dias, 2008] рассматривают, как официальное объявление конфликта между мажоритариями и миноритариями влияет на цену акций. Исследование базировалось на выборке из 24 случаев, обнародованных в Бразилии. Авторы пришли к выводу, что конфликт отрицательно сказывается на цене акций. Отрицательный эффект сохраняется на длительном временном интервале.

Буркарт, Громб, Панунзи [Burkart, Gromb, Panunzi, 1997] вместе с Пагано, Роэль [Pagano, Röell, 1998] показывают, что контроль со стороны акционеров приносит не только выгоды, но и издержки. Менеджеры становятся ограниченными в выборе инвестиционных возможностей, отказываются от прибыльных проектов, снижаются их стимулы к самостоятельности и выгоды от разделения и профессионализма.

При концентрации акций в одних руках у инвестора возникают проблемы с реализацией этого пакета по рыночной цене - издержки неликвидности. Также сильно возрастают риски инвестора, который держит средства крупным пулом в одной компании и издержки для менеджеров и компании в целом, которая вынуждена привлекать средства по завышенной стоимости капитала [см. Dyck, Zingales 2004, Demsetz, Lehn 1985]. Дик и Зингалес [Dyck, Zingales, 2004] выделяют также частные репутационные издержки менеджеров и мажоритариев.

\section{Список литературы}

1. Долгопятова Т.Г. Собственность и корпоративный контроль в российских компаниях в условиях активизации интеграционных процессов // Российский журнал менеджмента. - 2004. - Т. 2, № 2. - С. 3-26.

2. Ивашковская И.В., Зинкевич Н.В. Взаимосвязь характеристик корпоративного управления и эффективности компаний в системах с концентрированной структурой собственности: пример Германии // Корпоративные финансы. - 2009. - Т. 4, № 12. - С 34-56.

3. Ивашковская И.В., Степанова А.Н. Структура собственности как элемент корпоративной финансовой архитектуры: влияние на стратегическую эффективность компаний // Финансы и бизнес. - 2009. - № 3. - С 158-172.

4. Капелюшников Р. И. Крупнейшие и доминирующие собственники в российской промышленности: свидетельства мониторинга РЭБ // Российский Экономический Барометр. - 2000. - Т. 9, № 1. - С 9-46.

5. Кузнецов П.В., Муравьев А.А. Структура акционерного капитала и результаты деятельности фирм в России (анализ «голубых фишек» фондового рынка) // Экономический журнал Высшей школы экономики. - 2000. - Т. 4. № 4. - С 475-504.

6. Энтов Р.М., Радыгин А.Д., Межераупс И.В., Швецов П.А. Корпоративное управление и саморегулирование в системе институциональных изменений // Научные труды. М.: ИЭПП, - 2006. - № 101.

7. Black, B., Jang, H., and Kim, W. (2006), Does Corporate Governance Affect Firms' Market Values? Evidence from Korea, Journal of Law, Economics and Organization, 22 (2006) 366-413.

8. Burkart, M., Gromb, D., and Panunzi, F. (1997), Large Shareholders, Monitoring,and the Value of the Firm, Quarterly Journal of Economics, 112 (1997) 693-728.

9. Butz D. A. (1994), How do large minority shareholders wield control? Managerial and Decision Economics, 15(4) (1994) 74-81. 
10. Cronqvist, H., and Nilsson, M. (2003), Agency Costs of Controlling Minority Shareholders, Journal of Financial and Quantitive Analysis, 38 (4) (2003) 695-719.

11. Davies, J.R., Hillier, D.T., and McColgan, P. (2005), Ownership structure, managerial behavior and corporate value, Journal of Corporate Finance, 11 (2005) 645-660.

12. Demsetz, H. (1983), The Structure of Ownership and the Theory of the Firm, Journal of Law and Economics, 26 (1983) 375-390.

13. Demsetz, H., and Lehn K. (1985), The value of corporate voting rights and control: A crosscountry analysis, Journal of Political Economy, 93 (1985) 1155-1177.

14. Demsetz, H., and Villalonga, B. (2001), Ownership structure and corporate performance, Journal of Corporate Finance, 7 (2001) 209-233.

15. Dyck, A., and Zingales, L. (2004), Private Benefits of Control: An International Comparison, Journal of Finance, American Finance Association, 59(2) (2004) 537-600.

16. Fama, E.F., and Jensen, M.C. (1983), Separation of Ownership and Control, Journal of Law and Economics, 26 (1983).

17. Lazareva, O., Rachinsky A., and Stepanov, S. (2007), A Survey of Corporate Governance in Russia, NES Working Paper series (2007).

18. McConnell, J., and Servaes, H. (1990), Additional evidence on equity ownership and corporate value, Journal of Financial Economics, 27 (1990) 595-612.

19. Morck, R., Shleifer, A., and Vishny, R. (1988), Management ownership and market valuation: an empirical analysis, Journal of Financial Economics, 20 (1988) 293-315.

20. Nenova, T. (2002), The value of corporate voting rights and control: A cross-country analysis, Journal of Financial Economics, 68 (2003) 325-351.

21. Pagano, M., and Röell, A. (1998), The Choice of Stock Ownership Structure: Agency Costs, Monitoring, and the Decision to Go Public, Quarterly Journal of Economics, 113 (1998) $187-225$.

22. Silveira, A., and Dias, A. (2008), What are the Costs of Conflicts between Controlling and Minority Shareholders in a Concentrated Ownership Environment? Working Paper Series (2008) 1-30. 